\title{
A New Source of the Slavic Menaia
}

\author{
Tatiana Pentkovskaya \\ Professor of the Russian Language Department, Faculty of Philology, \\ Lomonosov Moscow State University, Moscow, Russia \\ pentkovskaia@gmail.com
}

Искра Христова-Шомова, Драготин миней. Български ръкопис от началото на ХІІ в. запазен като палимпсест в Драготиния апостол (нБкм 880 ). Научен редактор Хайнц Миклас. Редактор на гръцките текстове Иван Петров. (Библиотека Охридски извори). София: Университетско издателство «Св. Климент Охридски», 2018, р. 751.

Iskra Hristova-Shomova, Dragotin Menaion. Bulgarian manuscript of the early 12th century preserved as a palimpsest of Dragotinian Apostle (CMNL 880). Scholarly editor: Heinz Miklas. Editor of the Greek texts: Ivan Petrov. (Library of Ohrid Sources). Sofia: University Publishing House "St. Kliment of Ohrid", 2018.

\begin{abstract}
The article is devoted to the newest edition of the so-called Dragota Menaion prepared by Iskra Hristova-Shomova. This Bulgarian hymnographic collection survived as the bottom layer of a palimpsest going back to the early twelfth century. It combines the services of the Menaion and the Triodion cycles. The translation contains rare Slavonic lexemes and some archaic Greek borrowings. These features makes this text precious for the studies of liturgy and hymnography among the Slavs.
\end{abstract}

\section{Keywords}

Menaia - Triodion - Slavic liturgy - Slavonic hymnography - Slavonic palimpsest 
The book is a culmination of Iskra Hristova-Shomova's years-long meticulous study of the palimpsest part of Manuscript 88 o from the collection of the SS. Cyril and Methodius National Library in Sofia (CMNL).

The discovery of such a source and its introduction into the academic discourse is a great research achievement in itself. The story of reading the hidden layer in CMNL Manuscript 880, which began over 20 years ago and was dramatic at times, is narrated by Hristova-Shomova in the preface under the heading Opus vitae. This brings to mind another outstanding discovery of this kind - the Cyrillic Aprakos Gospel dating back to the middle of the tenth century. It was found in the 198 os by the Bulgarian scholar Trendafil Krastanov in the Vatican Library (Vat. Gr. 2502); the text had been probably washed off in the late twelfth or the early thirteenth century to clear the space for the Greek Gospel. ${ }^{1}$

The top layer of CMNL Manuscript 88o is a copy of the late twelfth - early thirteenth century Apostolos named by Hristova-Shomova after the scholar Dragota, who had left an adscript on p. 153a. It is a long-standing tradition to name sources on the basis of personal names or aliases of the scribes mentioned in the colophons (see, e.g. the name "Elijah's Book" for the Slavic-andRussian hymnographic collection at the Russian State Archive of Ancient Documents, Pr. 131, last quarter of the eleventh century, containing Menaion propers in its current version. ${ }^{2}$

The underlying layer of the manuscript presents a special Menaion, which acquired the name of Dragota in accordance with the top-layer Apostolos. The suggested dating of the Dragota Menaion (early twelfth century), its origin, archaic features and the amount of text preserved make this record genuinely unique.

1 Т. Кръстанов, “Български Ватикански палимпсест (Кирилско кратко изборно евангелие от Х в. в Cod Vat. gr. 2502)" [T. Krastanov, "A Bulgarian Palimpsest from the Vatican Library (Cyrillic Short lectionary Gospel of the 1oth century in Cod Vat., 2502)"], Palaeobulgarica, 1 (1988), pp. 36-66; Ватиканско евангелие. Старобългарски кирилски апракос от 10 век в палимпсестен кодекс Vat. Gr. 2502. Подготвили за издаване: Т. Кръстанов, А.-М. Тотоманова, И. Добрев [The Old Bulgarian Cyrillic Gospel Lectionary of the 1oth century in the Palimpsest Codex Vat. Gr. 2502. Prepared by T. Krastanov, A.-M. Totomanova, I. Dobrev]. Sofia, 1996.

2 Е.М. Верещагин, В.Б. Крысько, "Наблюдения над языком и текстом архаичного источника - Ильиной книги" [E.M. Vereshchagin, V.B. Krysko, "Some observations on the language and text of an archaic linguistic monument - The Eliah's Book"], Bonросы языкознания [Topics in the study of language], (1999), Nr 2, pp. 3-26, at p. 3; Е.М. Верещагин, Ильина книга: древнейший славянский богослужебный сборник. Факсимильное воспроизведение рукописи, билинеарно-спатическое издание источника с филологобогословским комментарием [E.M. Vereshchagin, The Elijah's Book: An Ancient Slavic Liturgical Collection. Facsimile Reproduction of the Manuscript, Bilinear and Spatic Edition with Philological and Theological Commentaries], Moscow, 2006, pp. XII-XIII. 
The dating is based on the confusion of nasal vowels (exchange of the yuses) in various positions frequently occurring in the manuscript. This phenomenon is accompanied by archaic features of writing identified by omission: absence of superscript (except two dots above some vowels), absence of wide variants for the graphemes $\mathfrak{e}$ and 0 , as well as absence of double $\mathrm{N}$ in past passive participles and absence of omission of reduced sounds before enclitics. All the graphic and spelling features absent are common to manuscripts of the subsequent period (p. 99). The forms of letters in the Menaion are consistent with the writing features of the late eleventh - early twelfth century (p. 41).

A remarkable feature of the manuscript is the predominant use of $\mathbf{z}$ and the writing of zi with the first element $\mathrm{z}$. The grapheme $\mathbf{b}$ is used only twice (съмрть and памать), in both cases written with two dots above it (p. 49). Note that the list of letters of the manuscript on p. 41 does not include the graphemes ie and iA as part of the manuscript, although their forms are discussed further (on pp. $5^{2}$ and 53 ). The letter $\mathrm{r}$ a appears only once, and $\mathrm{s}$ is absent.

The analysis of spelling also provides an opportunity to localise the Dragota Menaion. A number of parameters - transition of $\mathrm{z}$ to $\mathrm{o}$ in all morphemes, $\mathrm{z}$ in place of $\pi$, initial iotation in present forms of the verb выти, preservation of $[\mathrm{dz}]$ and loss of l'epentheticum - taken together indicate the Ohrid dialect. The first two major features are also typical of the Dragota Apostolos, leading the author to the conclusion that the two layers of the manuscript come from the same region (p. 100).

Researchers have already made two general observations regarding the earliest South Slavic copies of the Menaion. First, they are represented only by fragments: the Glagolitic festal Menaion of the eleventh - twelfth centuries from Saint Catherine's Monastery in the Sinai Sin. slav. $4 / \mathrm{N}$, a fragment of the Glagolitic palimpsest in the service book at the Russian State Historical Museum, Khlud. No. 117 (eleventh - twelfth centuries), a page with fragments of services for August at the Russian State Library, f. 87 (collection of V.I. Grigorovich) No. 1727, Ostrozhnitskie fragments of the eleventh - twelfth centuries, which are fragments of the canon of Saint Demetrios of Thessaloniki, a fragment of the Cyrillic palimpsest with Glagolitic letters of the twelfth century from the library of the Greek Orthodox Church of Jerusalem (Jerus. 19), festal Menaion for May (Hilferding's fragment) of the late twelfth - early thirteenth century (National Library of Russia, Q.п.I.25), two pages from the same manuscript stored at the same library under the code Q.п.I.28 (Amphilochius's fragments). ${ }^{3}$ Second, these fragments have often been preserved as part of 
other manuscripts. ${ }^{4}$ The source published by I. Hristova-Shomova belongs to this group as well, however, it stands out due to its considerably larger scope of material.

As noted by Roman N. Krivko, the liturgical Menaia are not included in the Old Slavonic corpus, therefore, they have not been reflected in the corresponding dictionaries. ${ }^{5}$ The vocabulary of the Dragota Menaion is tackled in a separate section of the study (pp. 93-97). It registers rare lexemes present in the

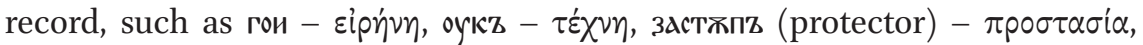

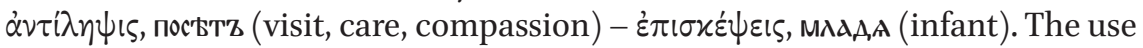
of these lexemes, as well as some archaic Greek borrowings (акротомz, крипида, мигав, шхокарфост, шмоУ'си, шсина, продромz) replaced in other copies by Slavic words allows Hristova-Shomova to attribute the texts of the record to the early stage of the Menaion functioning, “още в първите десетилетия след пристигането на Кирило-Методиевите ученици в България" (even in the first decades after the arrival of Cyril and Methodius' disciples in Bulgaria) (p. 96).

Among the record's Greek borrowings, two lexemes representing liturgical terminology are of particular interest. They are termini technici presented in

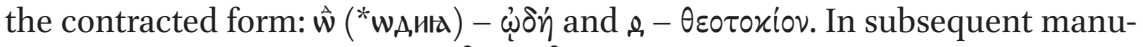
scripts they are replaced with п宅 and ถ̊ respectively (p. 96). I. Hristova-Shomova notes that the short form $\Theta$ to denote theotokia is found in certain parts of the thirteenth-century Dragan's Menaion (p. 25). It should be added that the term wАни is recorded in the Typikon of John of Patelaria: Russian State Li-

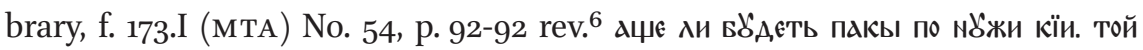

H.А. Нечунаева, “Минея: история текста и списков XI-XIV вв." [N.A. Nechunaeva, "Menaion: the history of the text and the history of the manuscripts of the 1oth-11th centuries"], in: Славянское языкознание: покидая XX век. К ХIV Международному съезду славистов (Охрид, 10-16.о9.20о8). Под ред. А.Д. Дуличенко. [Slavic Linguistics: Leaving the Twentieth Century... For the 14th International Congress of Slavists (Ohrid, 10-16.09.2008). Ed. by A.D. Dulichenko], Tartu, 2008, pp. 9-23, at p. 13; И. Христова-Шомова, “Две южнославянские минеи в сравнении с новгородскими минеями” [I. Hristova-Shomova, "Two South Slavic Menaia Compared with the Novgorod Menaia"], Древняя Русь. Вопросы медиевистики [Old Rus': The Questions of Middle Age Studies], (2009), Nr 4, pp. $44-62$.

Р.Н. Кривко, Очерки языка древних иерковнославянских рукописей. 2-е изд., испр. и доп. [R.N. Krivko, Essays in the Language of Early Church Slavonic Manuscripts. 2nd ed., corr. and augmented]. Moscow, 2018, p. 310.

6 The collection is known as "Ustyug version of the Nomocanon" (Joasaph copy): <http:// old.stsl.ru/manuscripts/big.php?col=5\&manuscript=054\&pagefile=054-0094 $>; \quad$ http:// old.stsl.ru/manuscripts $/$ medium.php? $\mathrm{col}=5 \&$ manuscript $=054$ \&pagefile $=054$-0og6 $>$. Data extracted on 03.01.2019. Currently the Joasaph academic copy is connected with the work of Metropolitan Daniel's employee Niphon (Kormilitsyn), hegumen of Joseph-Volokolamsk monastery: it could have been commissioned by Niphon to prepare the Nomocanon circa 1532 in the metropolitan's scriptorium. See A.А. Манохин, “Академический Иоасафовский список Устюжского сборника как исторический источник” 


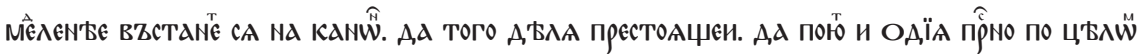

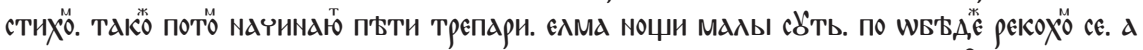

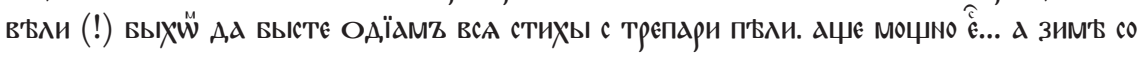

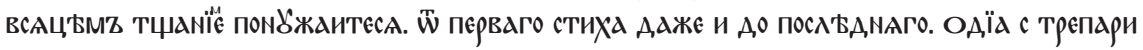
п'тти, ${ }^{7}$ which was preserved in the Slavic translation likely to have been made in the First Bulgarian Empire in the tenth century. ${ }^{8}$

The use of these terms probably dates back to the period when the use of the Byzantine melos was widespread in the Slavic liturgical practice (up to the middle of the tenth century). ${ }^{9}$

The archaic nature of the source is also shown in the composition and structure of the record. A major feature of the macro-composition of the Dragota Menaion is that it combines the services of the Menaion and the Triodion cycles: the Ascension service is between the services of St. George (23 April) and St. Achilles (15 May); ${ }^{10}$ moreover, it includes the service of St. Theodore Tyron (17 February), which is usually not included in the old recension of service $\mathrm{Me}$ naia, but corresponds textologically to the service in the Triodion of the Saturday on the first week of the Great Lent. Another Triodion text presents the chants of the Akathist to the Theotokos. All of the above enables I. Hristova-

[A.A. Manokhin, "Joasaph Academic Copy of Ustyug Collection as a Historical Source"], Вестник пстгу. Серия II: История. История Русской Православной Церкви [St. Tikhon's University Messenger. Series II: History. History of the Russian Orthodox Church], (2017), issue 76, pp. 11-21, at pp. 13, 17 .

7 И.Д. Мансветов, Церковный Устав (Типик), его образование и судьба в Греческой и Русской Церкви [I.D. Mansvetov, The Ecclesiastical Typikon, Its Formation and Destiny in the Greek and Russian Churches], Moscow, 1885, p. 444; A.М. Пентковский, “Литургическая терминология в византийско-славянской контактной зоне” [A.M. Pentkovsky, "Liturgical Terminology in the Byzantine-Slavic Contact Zone"], in: Славяне и их соседи. ХХ конференция памяти В.Д. Королюка. Становление славянского мира и Византия в эпоху раннего Средневековья [Slavs and Their Neighbors. 2oth Conference in Memory of V.D. Korolyuk: The Establishment of the Slavic World and Byzantium in the Early Middle Ages Period], Moscow, 2001, pp. 86-9o, at p. 88.

8 “Иоанн прп., исп." [“John, Saint Monk, Confessor”], in: Православная энииклопедия [The Orthodox Encyclopaedia], vol. 23, Moscow, 2010, p. 249. This text is dated to the twelfth century by Yaroslav N. Schapov without any argumentation: Я.Н. Щапов, Византийское и южнославянское правовое наследие на Руси в ХI-ХІІІ вв. [Yа. N. Schapov, Byzantine and South Slavic Legal Heritage in Rus' in the nth-13th cent.], Moscow, 1978, p. 193.

9 А.М. Пентковский, "Материалы для истории славянского богослужения в XI веке: I. Восточно- и южнославянские служебные Минеи” [A.M. Pentkovsky, "Materials for the History of Slavic Liturgy in the Eleventh Century. Part I: East and South Slavic Liturgical Mепаіа"], Труды Института русского языка им. В.В. Виноградова [Proceedings of the V.V. Vinogradov Russian Language Institute ], 16 (2018), pp. 245-295, at p. 256.

10 It should be noted that the subsequent Menaia of the "Studion type" for 15 May contain liturgical propers of St. Pachomius the Great and St. Theodore, and the Studion and Alexios rules feature only liturgical records to commemorate St. Pachomius the Great: Пентковский, Материаль для истории славянского богослужения, р. 25 о. 
Shomova to describe the record not as a "traditional festal Menaion, but rather a Menaion and Triodion collection" (p. 26). This feature, in its turn, brings the Dragota Menaion together with the already known Menaia of special composition, i.e. hymnographic collections including Menaion and Triodion services and dating back to the early Byzantine Tropologion, which combined services of the Menaion, Triodion and Weekly cycles (p. 27). Thus, the Dragota Menaion is attributed to the initial stage of the Old Bulgarian hymnography, when the services were placed in the aggregate Menaion and Triodion collections (p. 30). This finding is in good agreement with the archaic linguistic features of the service texts, as well as the nature of the translation methodology characterised by lack of the literalism that appears later (p. 31).

Publication of the Dragota Menaion service texts is supplemented with the Greek bitext (where available), moreover, the relevant texts of Slavic manuscripts with the same chants are provided. Further the author presents an analysis of the composition and text of each Dragota Menaion service, which is always completed by a summary table of the service composition based on a range of sources. This comparative part is far beyond the scope of publication and study of one record. Thus, the multi-source analysis of the Annunciation service composition and text allows, inter alia, grouping them by the number of troparia in the canon ode: in the early version, where the Dragota Menaion is attributed, an ode included five troparia, and in the later versions there were four of them. Additional Theotokos troparia were excluded upon alignment with the contemporary Greek sources. Hristova-Shomova believes that it took place in the tenth century in the Preslav literary centre. Overall, "most hymns of the Dragota Menaion are known by other manuscripts in a new, more recent version, which is likely to have appeared in the tenth-century Preslav". This large-scope editing is characterised by alignment of the text with the contemporary Greek variants, as well as a trend to establish fixed Slavic-Greek correspondences in vocabulary, morpheme-by-morpheme translation and reproduction of the syntactic features of Greek phrases (p. 31, 392, 403-404).

A considerably modified outlook on the stages of hymnographic texts (including service Menaia) development has been proposed recently. Alexey M. Pentkovsky has reconstructed, as the earliest stage of their development, the so-called "Clement corpus" (CC) created in 893-916 in the Slavic bishopric of St. Clement of Ohrid. It included a set of hymnographic texts for the annual immovable, annual movable and weekly service cycles covered by the Menaia, Triodia and Octoechos (CC-2). The texts of CC-2 were attributable to the SouthWestern group of the South Slavic linguistic area and were recorded in the Glagolitic alphabet. In the middle of the tenth century, this set was revised and supplemented, with the result of developing an updated collection of 
hymnographic texts translated word by word (a set of service Menaia, Triodia and Octoechos), aligned with the respective Greek texts (CC-3). Their language was also defined as being of the South-Western group, and the alphabet was Glagolitic. The second half of the tenth century saw the appearance of the Cyrillic version CC-3, which functioned on the territory of Samuel of Bulgaria's state after the Eastern part of the First Bulgarian Empire was captured by the Byzantines in 971. This Cyrillic version was brought to Rus after its official baptism in 988. Finally, Old Russian "Studion" Menaia and Old Serbian concise and "Evergetid" Menaia descend from the shared South Slavic archetype of service Menaia, which probably appeared in Ohrid in the eleventh century (SSAM).11 Apparently, this reconstruction allots the Preslav literary centre a much lesser role than it was traditionally recognised.

What could be the place of the Dragota Menaion in this system? The following features found by Hristova-Shomova in the structure of the source should come into focus. It is the position of the sessational hymn in most services after the third ode of the canon (p. 33-34). ${ }^{12}$ Placement at the end of the service propers (after the canon and the stichera) is reconstructed by Pentkovsky for CC- $3 .^{13}$

Kontakia and oikoi are presented in the Dragota Menaion in a very inconsistent manner. Services to St. George, Ascension, St. Achilles, St. Cosmas and Damian contain no kontakia and oikoi, which leads Hristova-Shomova to the conclusion that there were no kontakia and oikoi in the primary source of the Dragota Menaion and, most likely, the earliest composition of Old Bulgarian services did not include kontakia and oikoi (p. 34). The "initial absence" of kontakia in CC-3 is indicated by Pentkovsky. ${ }^{14}$ The possible attribution of the Dragota Menaion to CC-3 is also supported by the old Greek borrowings retained in the language of the services: "systemic replacement of Greek borrowings with their Slavic equivalents was a typical feature of editing hymnographic texts during the transition from CC-3 Menaia to sSAM"."15

The publication includes Old Bulgarian - Greek concordance (p. 561665 ), covering not only notional, but also auxiliary parts of speech. The

Пентковский, Материалы для истории славянского богослужения, pp. 246-249, 275276 .

"The data of the Dragota Menaion enable us to assume that sessational hymns were already included in the earliest composition of Old Bulgarian services and, apparently, they were placed in the Old Bulgarian hymnographic books after the third ode of the canon" (p. 34).

13 Пентковский, Материаль для истории славянского богослужения, р. 263-264.

14 Пентковский, Материалы для истории славянского богослужения, p. 263.

15 Пентковский, Материаль для истории славянского богослужения, p. 269. 
lemmatisation was based on the publication principles [Old Bulgarian Dictionary 1999 and 2009]. Furthermore, there is also a reverse Greek - Old Bulgarian index of lexemes (p. 667-686).

A separate section is formed by incipitaria: the Slavic-Greek incipitarium of the Dragota Menaion hymns (p. 689-707) and the incipitarium of Greek hymns and their Old Bulgarian correspondences in the Dragota Menaion (p. 709-721).

The publication concludes by two supplementary articles outlining the technical aspects of the palimpsest analysis and its preparation for issue (p. 737-742 and 743-751). These are The Images of the Dragotin Palimpsest Provided by the Centre of Image and Material Analysis in Cultural Heritage (by Fabian Hollaus, Simon Brenner, Heinz Miklas) and Spectroscopic Material Investigations of the Palimpsest-Codex No. 880 of the Bulgarian National Library "Ss. Cyril and Methodius" (by Bernadette Frühmann, Wilfried Vetter, Manfred Schreiner).

The publication and study of the Dragota Menaion is characterised by outstanding depth of research. It contributes significantly to historical Bulgarian, Paleoslavic and liturgical studies.

Translated by Inna N. Fomina 